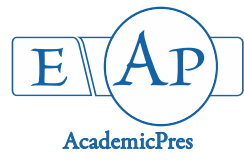

\title{
The Effects of Using Synthetic and Natural Color Foods on Lipid Profile and Liver Function in Rats
}

\author{
Emam ABDEL-RAHIM ${ }^{1}$, Hossam S. EL-BELTAGI ${ }^{1,2}$, Rehab F. M. ALI ${ }^{1,3 *}$, \\ Abeer A. AMER ${ }^{4}$, Somia M. MOUSA ${ }^{4}$ \\ ${ }^{1}$ Cairo University, Faculty of Agriculture, Biochemistry Department, P. Box 12613, Gamma St, Giza, Cairo, Egypt; malkelanany@gmail.com \\ ${ }^{2}$ King Faisal University, Agriculture Biotechnology Department, College of Agriculture and Food Sciences, P.O. Box 420, \\ Al-Ahsa 31982, Saudi Arabia \\ ${ }^{3} \mathrm{Al}$-Qassim University, College of Agriculture and Veterinary Medicine, Food Science and Human Nutrition Department, \\ Qassim Kingdom of Saudi Arabia \\ ${ }^{4}$ Food Technology Research Institute, Agricultural Research Center, Giza, Egypt
}

\begin{abstract}
Today synthetic food dyes are being used most commonly as food colorant in confectionaries for children. Present study was designed to evaluate effect of tartrazine and chocolate brown as a synthetic color and turmeric, cocoa as a natural color on Swiss albino mice. The rats have been fed on color biscuits and after the acclimation period, rats were divided into 7 groups ( 5 rats each one). Rats treated with dose level $7.5 \mathrm{mg} / \mathrm{kg} /$ day (ADI) in tartrazine and turmeric and $0.15 \mathrm{mg} / \mathrm{kg} / \mathrm{day}$ (ADI) in chocolate brown and cocoa. The study revealed a highly noticeable decrease in the body weight gain, food intake and feed efficiency in synthetic color of mice compared to the control group, the mixture improvement this effects and non-significant with natural color. A significant increase in the average weight of the major organs liver, spleen, heart, pancreas and kidney of the mice has been increased significantly in synthetic color treated groups with tartrazine and chocolate brown. Total cholesterol level, T-lipid, LDL and vLDL were no significant change in all mice administration color foods, but significant increase in T.G with tartrazine and chocolate brown and has significant decrease in HDL-C with tartrazine and chocolate brown. There was a significant increase in the level of ALT, AST and ALP with tartrazine and chocolate brown while compared to control group. The mixture synthetic and natural color improved the results. Bilirubin levels were significantly increased with tartrazine and chocolate brown.
\end{abstract}

Keywords: children; cholesterol; chocolate brown; natural color; synthetic color; tartrazine

\section{Introduction}

Colors in food constitute an essential part of our life. Several years ago, the technology for processing food changed completely. Use of synthetic dyes, either separately or mixed for coloring foods, became more prevalent. That trend is stronger in Europe than the United States, but some U.S. companies recognize that an "All Natural" label can attract customers and may be moving in that direction (Barrett et al., 2007). Some of synthetic coloring additives cause severe tension to the consumer as general health for example tartrazine E102 and chocolate brown as synthetic coloring agents caused DNA liver and kidneys damage as detected by comet assay (Hassan, 2010).
Dried Curcuma longa (turmeric) is the source of the spice turmeric, the ingredient that gives curry powder its characteristic yellow color. Turmeric is used extensively in foods for both its flavor and color. Turmeric has a long tradition of use in the Chinese and Ayurvedic systems of medicine, particularly as an anti-inflammatory agent, and for the treatment of flatulence, jaundice, menstrual difficulties, hematuria, hemorrhage, and colic (Lung, 1980).

Cocoa powder is an important ingredient in the manufacture of numerous foods and beverages as a color and flavor in like dessert powders, sterilized chocolate milk, chocolate cake, ice-cream, etc. (Biehl and Ziegleder, 2003).

The present study was designed to evaluate the effect of tartrazine and chocolate brown as a synthetic color and turmeric, cocoa as a natural color on the on lipid profile and liver function in albino rats. 
364

\section{Materials and Methods}

Wheat flour $72 \%$ extraction was obtained from wheat research section, Field Crops Research Institute, Agricultural Research Center, Giza, Egypt. Sugar, shortening, vanilla, egg, baking powder and salt (sodium chloride) were obtained from the local market of Giza, Egypt.

Natural color: Turmeric and cocoa were purchased from the local market of Giza, Egypt.

Synthetic color: tartrazine yellow and chocolate brown colors were obtained from Imperial Chemical Industries.

Mixed color: tartrazine/turmeric and cocao/chocolate brown mixture were prepared by adding each one to the other in ratio of 1:1 (w/w). The colorant samples were used to give yellow and brown food stuff colorants.

\section{Wheat flour biscuit preparation}

The mixing procedures and the ingredients are summarized in Table 1 . The dough was rolled out to a thickness of $5 \mathrm{~mm}$ using a rolling pin and was then cut out with a $3 \mathrm{~cm}$ diameter biscuit cutter. The formulated biscuits were baked in an electric oven for $9 \mathrm{~min}$ at $170{ }^{\circ} \mathrm{C}$. The biscuit samples were allowed to cool in cooling chamber $(15$ ${ }^{\circ} \mathrm{C}$. The nutritional experiment was carried out on the ground samples.

\section{Animals}

Sampling and chemical analysis

Health adult male albino rats ( 35 animals) rats weighing (25-30 g) were obtained from the Animal House at the Food Technology Research Institute, (Agricultural Research Center, Giza, Egypt). The animal experiments were conducted according to the recommendations in the Guide of National Institutes of Health Publication no. 85-23, revised 1996). The experimental design and handling procedures were approved by the Ethics Committee of Faculty of Agriculture, Cairo University. Every effort was made to minimize the number of animals used ( 35 rats) and their suffering. Following one week to acclimatize to the American Institute of Nutrition (AIN)-93 G diet (Reeves, 1993), the rats were randomly divided into 7 groups $(n=5)$ for a period of 9 weeks. The animals were weighed at the initial and final experiment period.

\section{Experimental design}

Experiment of healthy young albino rats fed on colored wheat biscuits

Rats were divided into 7 groups (5 rats each one).

G1: healthy young rats were fed on less color biscuits as normal health control.

G2: healthy young rats were fed on the turmeric colored biscuits ( $7.5 \mathrm{mg} / \mathrm{kg}$ body weight).

G3: healthy young rats were fed on the cocoa colored biscuits ( $0.15 \mathrm{mg} / \mathrm{kg}$ body weight).

G4: healthy young rats were fed on the tartrazine colored biscuits $(7.5 \mathrm{mg} / \mathrm{kg}$ body weight).

G5: healthy young rats were fed on the chocolate brown colored biscuits ( $0.15 \mathrm{mg} / \mathrm{kg}$ body weight).

G6: healthy adult rats were fed on the turmeric biscuits tetrazine mixture biscuits $(7.5 / 7.5 \mathrm{mg} / \mathrm{kg}$ body weight respectively).

G7: healthy adult rats were fed on the cocoa biscuits chocolate brown mixture biscuits $(0.15 / 0.15 \mathrm{mg} / \mathrm{kg}$ body weight respectively).

Feed efficiency: Feed efficiency was calculated as the following equation:

Feed efficiency $=($ Daily body weight gain $/$ Daily food intake).

\section{Organs weight and blood plasma preparation}

After 9 weeks of treatment rats the rats were fasted overnight. All the animals were sacrified by cervical decapitation. Samples blood was collected from each rat from the retro orbital vein technique by heparinized capillary tube into clean and dry tubes. The tubes contained heparin as anticoagulant some of each was centrifuged at $3000 \mathrm{rpm}$ to obtain the plasma which was kept frozen at -20 ${ }^{\circ} \mathrm{C}$ until used for analysis for total lipid, total cholesterol, T.G, LDL, HDL, vLDL, AST, ALT, ALP and bilirubin.

\section{Sample preparation for biochemical studies}

Liver were rapidly remove weighed, put in ice-cold $1.15 \% \mathrm{KCl}$ and stored at $20{ }^{\circ} \mathrm{C}$ for homogenization to determine. The body weight gain and internal organ to body weight ratio were estimated. Some vital organs such as liver, heart, spleen, pancreas and kidneys were removed after sacrificing rats and their weight were recorded but liver was kept for some analysis. Plasma was used for the biochemical parameters, which were assayed by standard methods.

Determination of plasma total lipids: Total lipids in plasma were determined according to the method described by Knight et al. (1972).

Determination of plasma total cholesterol (TC): plasma cholesterol was determined by the method described by Allain et al. (1974).

Determination of serum HDL - cholesterol: plasma HDL- cholesterol was determined by the method described by Burstein (1970).

Determination of plasma LDL - cholesterol: plasma LDL- cholesterol was determined by the method described by Levy (1981).

Determination of plasma triglycerides: plasma triglycerides content was determined using the method described by Fossati and Prencipe (1982).

Very low density lipoprotein- cholesterol (VLDL-c): Very low density lipoprotein- cholesterol (VLDL-c) was calculated as follows according to Levy et al. (1981).

$\mathrm{VLDL}=\mathrm{TG} / 5$.

Determination of plasma transaminases: colorimetric determination of AST activity in plasma according to the method described by Reitman and Frankel (1957).

Determination of ALT activity: colorimetric determination of AST activity in plasma according to the method described by Reitman and Frankel (1957).

Determination of plasma total bilirubin: the determination of total bilirubin was carried out according to the method described by Walter and Gerarde (1970)

Determination of plasma ALP activity: colorimetric determination of alkaline phosphatase activity according to the method of Belfield and Goldberg (1971). 
Table 1. Formulation of wheat flour biscuit with different levels of colorants

\begin{tabular}{|c|c|c|c|c|c|c|c|c|}
\hline Biscuit & $\begin{array}{l}\text { Wheat } \\
\text { flour }\end{array}$ & Sugar & Shortening & Dye & Vanilla & Egg & $\begin{array}{l}\text { Baking } \\
\text { powder }\end{array}$ & Salt \\
\hline G1 & $100 \mathrm{~g}$ & $30 \mathrm{~g}$ & $30 \mathrm{~g}$ & (-.-- & $1-2 \mathrm{~g}$ & $15 \mathrm{mg}$ & $2-3 g$ & $1 \mathrm{~g}$ \\
\hline G2 & $100 \mathrm{~g}$ & $30 \mathrm{~g}$ & $30 \mathrm{~g}$ & $7.5 \mathrm{mg} / \mathrm{kg}(\mathrm{bw}) /$ day & $1-2 \mathrm{~g}$ & $15 \mathrm{mg}$ & $2-3 g$ & $1 \mathrm{~g}$ \\
\hline G3 & $100 \mathrm{~g}$ & $30 \mathrm{~g}$ & $30 \mathrm{~g}$ & $0.15 \mathrm{mg} / \mathrm{kg}(\mathrm{bw}) /$ day & $1-2 \mathrm{~g}$ & $15 \mathrm{mg}$ & $2-3 g$ & $1 \mathrm{~g}$ \\
\hline G4 & $100 \mathrm{~g}$ & $30 \mathrm{~g}$ & $30 \mathrm{~g}$ & $7.5 \mathrm{mg} / \mathrm{kg}(\mathrm{bw}) /$ day & $1-2 \mathrm{~g}$ & $15 \mathrm{mg}$ & $2-3 \mathrm{~g}$ & $1 \mathrm{~g}$ \\
\hline G5 & $100 \mathrm{~g}$ & $30 \mathrm{~g}$ & $30 \mathrm{~g}$ & $0.15 \mathrm{~g} / \mathrm{kg}(\mathrm{bw}) /$ day & $1-2 g$ & $15 \mathrm{mg}$ & $2-3 g$ & $1 \mathrm{~g}$ \\
\hline G6 & $100 \mathrm{~g}$ & $30 \mathrm{~g}$ & $30 \mathrm{~g}$ & $15 \mathrm{mg} / \mathrm{kg}(\mathrm{bw}) /$ day & $1-2 \mathrm{~g}$ & $15 \mathrm{mg}$ & $2-3 g$ & $1 \mathrm{~g}$ \\
\hline G7 & $100 \mathrm{~g}$ & $30 \mathrm{~g}$ & $30 \mathrm{~g}$ & $0.3 \mathrm{~g} / \mathrm{kg}(\mathrm{bw}) /$ day & $1-2 g$ & $15 \mathrm{mg}$ & $2-3 g$ & $1 \mathrm{~g}$ \\
\hline
\end{tabular}

\section{Statistical analysis}

Statistical analysis standard deviation (SD) was carried out according to Fisher (1970). Statistical analysis, data were obtained for different variables analyzed using ANOVA analysis by SAS program according to Cary (1998).

\section{Results and Discussion}

Table 2 presents the initial and final body weights, body weight gain, food intake and feed efficiency of the experimental rats. No significant $(P \geq 0.05)$ differences in weight gain and feed intake between the control group and these groups fed on biscuits supplemented with turmeric and cocoa were observed. However, significant differences $(\mathrm{P}<0.05)$ in weight gain and feed intake among treatments were observed (Table 2). The weight gain of the rats fed the synthetic dyes was significantly lower than those rats fed the control diet and natural dyes. The incorporation of tartrazine and chocolate brown into the diet caused significant $(\mathrm{P} \leq 0.05)$ reductions in the weight gain of rats. These reductions may be attributed to the the potential toxicological effects of tartrazine which alter the growth and weight gains. Arefin et al. (2017) considered the loss of body weight is a reliable sensitive biomarker indicator for toxicity study. It has been showed that tartrazine encourages the mutagenic activities (Stefanidou et al., 2003), and decreases the viability of the cell (Ashida et al., 2000). In this regard, Neshe et al. (2016) reported that children fed on food colours had adverse effects on a daily food intake behavior. Mixing synthetic dye with natural colours attenuated the adverse effects of synthetic colours (Table 2). These positive impacts may be due to the excellent antioxidant activity of natural colours which that prevent oxidation of other compounds or neutralize free radicals.

Table 3 illustrates the changes in the relative weights of organs from mices fed biscuits incorporated with natural dyes, synthetic dyes or mixture of them. The liver, kidneys, heart, spleen and pancreas significantly differed $(\mathrm{P} \leq 0.05)$ among the treated groups. The mices fed with the control diet had significantly $(\mathrm{P} \leq 0.05)$ the lowest liver, kidneys, heart, spleen and pancreas weights. Adminstration of synthetic colours for 9 weeks induced a significant increase $(\mathrm{P} \leq 0.05)$ in the ratio of liver, kidneys, heart, spleen and pancreas weights to body weight. The coadministration of natural dyes and synthetic dyes significantly $(\mathrm{P} \leq 0.05)$ reduced the liver, kidneys, heart, spleen and pancreas compared with these groups fed biscuits incorporated with synthetic colours (Table 3). The results in Table (3) indicated that the weight of liver, kidneys, heart, spleen and pancreas of the mice has been increased significantly in synthetic color treated groups with tartrazine $108 \%, 105 \%$, $112 \%, 111 \%$ and $108 \%$ and with chocolate brown was $107 \%, 107 \%, 113 \%, 113 \%$ and $110 \%$, respectively This results agree with Arefin et al. (2017) who found that that oral ingestion of synthetic dyes for 30 days in mice increased the liver and kidney weight.

Table 4 demonstrates the changes in serum total cholesterol level, T-lipid, LDL and vLDL levels in mices fed biscuits incorporated with natural dyes, synthetic dyes or mixture of them. No significant $(P \geq 0.05)$ differences in total cholesterol level, T-lipid, LDL and vLDL between the control group and these groups fed with natural dyes were observed. However, significant increases $(120 \%)$ in T.G with tartrazine and with chocolate brown $121 \%$, significant decrease in HDL-C with tartrazine 95\% and with chocolate brown $94 \%$ these findings are in good agreement with Soltan and Shehata (2012) who showed that serum total cholesterol level; HDL and LDL had no significant change in all rats' administration color foods color sweet and color chocolate at low (15\%) and high (30\%) on children. In the same time, significant increase in TG in group administration of chocolate and sweet colored at low and high concentrations. Our results are in accordance with the results obtained by Himiri et al. (2011) who observed significant increase in serum triglycerides of rats treated with synthetic color tartrazine and chocolate color that containing tartrazine and carmoisne. In this regard, ELDesoky et al. (2017) studied the serum levels of TC, LDL$\mathrm{C}$, and TG of rats exposed to tartrazine. They showed that these values were significantly greater compared to the controls, but there were no significant differences between concentrations of HDL-C and those of the controls. While, curcumin resulted in significantly lesser concentrations of TC, LDL-C and TG in blood serum compared with rats exposed to tartrazine without curcumin concentrations of TC and LDL-C in serum compared with control, and the concentration of TG was nearly equivalent to that of the controls.

Table 5 depicts the effect of experimental diets on the liver functions of rats. There was significant increase in the level of ALT with tartrazine and chocolate brown $118 \%$ and $117 \%$ respectively while AST $108 \%$ and $106 \%$ respectively compared to control group. The mixture synthetic and natural color improved the results with AST, ALT and ALP. Bilirubin levels were significantly increased with synthetic color $125 \%$ with tartrazine and $129 \%$ with chocolate brown Soltan and Shehata (2012) administration 
366

of color fruit juice and chocolate brown level of ALT was significant increase of group reached to $26.6 \%$. Also, the level of AST was significant increase in group administration of color at concentration $30 \%$ reached to $11.2 \%$ with children. A significant increase in serum ALT and AST may be attributed those change in liver function to be hepatocellular impairment level of intracellular enzymes into the blood (Abdel-Rahim et al., 1987). The release of a normally high level of specific tissue enzymes into blood stream is dependent on both the degree and type of damage exerted by the toxic compound administration Haward
(2005) supported these findings and revealed that this combination developing neuroblastoma in rat cells. Treating animals with the synthetic dye caused significant increase in the serum levels of ALT, AST and ALP. Damaged organs showed increase in enzyme activity. Chronic intoxication was accompanied by continuous increase in serum levels in both ALT and AST activities. These enzymes were liberated in the bloodstream following injury to the cells. The results of the present study showed significant increase in ALP activity for synthetic color may be attributed to the defects in liver function (Hayes, 1994).

Table 2. Body weight gain, food intake and feed efficiency of healthy young rats treated with wheat colored biscuits

\begin{tabular}{ccccccc}
\hline & \multicolumn{3}{c}{ Body weight } & & Food intake & \multicolumn{2}{c}{ Feed efficiency } \\
\cline { 2 - 7 } & Initial $(\mathrm{g})$ & Final $(\mathrm{g})$ & Gain $(\mathrm{g})$ & Values $(\mathrm{g})$ & Values & $\%$ \\
\hline G1 & $39.5 \pm 1.5$ & $107.71 \pm 4.2$ & $68.21 \pm 2.3 \mathrm{a}$ & $511 \pm 31.1$ & $0.133^{\mathrm{a}}$ & 100 \\
G2 & $40.1 \pm 1.7$ & $107.27 \pm 3.7$ & $67.17 \pm 3.0 \mathrm{a}$ & $529 \pm 27.2$ & $0.125^{\mathrm{ab}}$ & 94 \\
G3 & $38.9 \pm 2.0$ & $106.11 \pm 5.0$ & $67.21 \pm 3.8 \mathrm{a}$ & $532 \pm 28.4$ & $0.126^{\mathrm{a}}$ & 95 \\
G4 & $41.0 \pm 1.7$ & $104.21 \pm 3.1$ & $63.21 \pm 4.0 \mathrm{c}$ & $524 \pm 30.0$ & $0.121^{\mathrm{b}}$ & 91 \\
G5 & $40.12 \pm 2.1$ & $102.29 \pm 2.9$ & $62.17 \pm 2.9 \mathrm{c}$ & $512 \pm 27.4$ & $0.121^{\mathrm{b}}$ & 91 \\
G6 & $39.2 \pm 1.9$ & $104.64 \pm 3.2$ & $65.44 \pm 3.7 \mathrm{~b}$ & $526 \pm 26.9$ & $0.123^{\mathrm{ab}}$ & 92 \\
G7 & $39.6 \pm 1.8$ & $104.6 \pm 4.6$ & $65.00 \pm 4.1 \mathrm{~b}$ & $522 \pm 28.7$ & $0.125^{\text {ab }}$ & 94 \\
\hline
\end{tabular}

Values are mean \pm SD of three replicates. G1:control biscuits less color,G2:turmeric biscuit, G3: cocoa biscuits, G4:tartrazine biscuits, G5:chocolate brown biscuit, G6:mixture tartrazin and turmeric, G7:mixture chocolate brown and cocoa.

Table 3. Organs weight rates relative to the final weight of healthy young groups treated by colors wheat biscuits

\begin{tabular}{ccccccccccc}
\hline & Liver & \multicolumn{3}{c}{ Kidneys } & \multicolumn{2}{c}{ Heart } & spleen & \multicolumn{2}{c}{ Pancreas } \\
\cline { 2 - 11 } & Weight & $\%$ & Weight & $\%$ & Weight & $\%$ & Weight & $\%$ & Weight & $\%$ \\
\hline G1 & $3.46^{\mathrm{ab}} \pm 0.14$ & 100 & $1.51^{\mathrm{a}} \pm 0.08$ & 100 & $1.15^{\mathrm{b}} \pm 0.06$ & 100 & $0.91^{\mathrm{b}} \pm 0.05$ & 100 & $0.96 \pm 0.06^{\mathrm{ab}}$ & 100 \\
G2 & $3.44^{\mathrm{b}} \pm 0.16$ & 99 & $1.32^{\mathrm{b}} \pm 0.07$ & 87 & $1.11^{\mathrm{b}} \pm 0.05$ & 97 & $0.77^{\mathrm{b}} \pm 0.04$ & 96 & $0.91 \pm 0.05^{\mathrm{b}}$ & 95 \\
G3 & $3.43^{\mathrm{b}} \pm 0.12$ & 99 & $1.34^{\mathrm{b}} \pm 0.08$ & 79 & $1.12^{\mathrm{b}} \pm 0.07$ & 97 & $0.88^{\mathrm{b}} \pm 0.06$ & 97 & $0.90^{\mathrm{b}} \pm 0.04$ & 94 \\
G4 & $3.74^{\mathrm{a}} \pm 0.11$ & 108 & $1.59^{\mathrm{a}} \pm 0.06$ & 105 & $1.29^{\mathrm{a}} \pm 0.08$ & 112 & $1.01^{\mathrm{a}} \pm 0.06$ & 111 & $1.04^{\mathrm{a}} \pm 0.08$ & 108 \\
G5 & $3.72^{\mathrm{a}} \pm 0.18$ & 107 & $1.61^{\mathrm{a}} \pm 0.09$ & 107 & $1.30^{\mathrm{a}} \pm 0.09$ & 113 & $1.03^{\mathrm{a}} \pm 0.07$ & 113 & $1.06^{\mathrm{a}} \pm 0.07$ & 110 \\
G6 & $3.52^{\mathrm{b}} \pm 0.18$ & 102 & $1.56^{\mathrm{a}} \pm 0.06$ & 103 & $1.20^{\mathrm{b}} \pm 0.07$ & 104 & $0.93^{\mathrm{b}} \pm 0.06$ & 102 & $0.96^{\mathrm{b}} \pm 0.07$ & 100 \\
G7 & $3.60^{\mathrm{b}} \pm 0.17$ & 104 & $1.51^{\mathrm{a}} \pm 0.05$ & 100 & $1.23^{\mathrm{b}} \pm 0.10$ & 107 & $0.95^{\mathrm{b}} \pm 0.05$ & 104 & $0.98^{\mathrm{b}} \pm 0.08$ & 102 \\
\hline
\end{tabular}

Values are mean \pm SD of three replicates. G1:control biscuits less color,G2:turmeric biscuit, G3: cocoa biscuits, G4:tartrazine biscuits, G5:chocolate brown biscuit, G6:mixture tartrazin and turmeric, G7:mixture chocolate brown and cocoa.

Table 4. Values of lipid profile of normal young groups treated by wheat and color

\begin{tabular}{|c|c|c|c|c|c|c|c|c|c|c|c|c|}
\hline & \multicolumn{2}{|c|}{ T. lipid } & \multicolumn{2}{|c|}{ T. cholesterol } & \multicolumn{2}{|c|}{ Triglycerids } & \multicolumn{2}{|c|}{ LDL.c } & \multicolumn{2}{|c|}{ HDL.c } & \multicolumn{2}{|c|}{ Vldl.c } \\
\hline & $\mathrm{mg} / \mathrm{dl}$ & $\%$ & $\mathrm{mg} / \mathrm{dl}$ & $\%$ & $\mathrm{mg} / \mathrm{dl}$ & $\%$ & $\mathrm{mg} / \mathrm{dl}$ & $\%$ & $\mathrm{mg} / \mathrm{dl}$ & $\%$ & $\mathrm{mg} / \mathrm{dl}$ & $\%$ \\
\hline \multirow{2}{*}{ G1 } & $599.16^{a}$ & \multirow{2}{*}{100} & $181.11^{a}$ & \multirow{2}{*}{100} & $199.78^{b}$ & \multirow{2}{*}{100} & $35.00^{2}$ & \multirow{2}{*}{100} & $42.12^{2}$ & \multirow{2}{*}{100} & $39.96 \mathrm{a}$ & \multirow{2}{*}{100} \\
\hline & \pm 37.71 & & \pm 11.01 & & \pm 11.21 & & \pm 2.01 & & \pm 3.01 & & \pm 3.01 & \\
\hline \multirow{2}{*}{ G2 } & $572.34^{a}$ & \multirow{2}{*}{96} & $174.21^{\mathrm{a}}$ & \multirow{2}{*}{96} & $200.00^{b}$ & \multirow{2}{*}{100} & $34.11^{\mathrm{b}}$ & \multirow{2}{*}{97} & $43.33^{a}$ & \multirow{2}{*}{103} & $37.68^{2}$ & \multirow{2}{*}{96} \\
\hline & \pm 40.12 & & \pm 10.12 & & \pm 12.13 & & \pm 1.98 & & \pm 2.94 & & \pm 2.94 & \\
\hline \multirow{2}{*}{ G3 } & $571.11^{a}$ & \multirow{2}{*}{95} & $176.00^{\mathrm{a}}$ & \multirow{2}{*}{97} & $202.00^{b}$ & \multirow{2}{*}{101} & $34.00^{\mathrm{b}}$ & \multirow{2}{*}{97} & $44.00^{2}$ & \multirow{2}{*}{104} & $38.20^{2}$ & \multirow{2}{*}{97} \\
\hline & \pm 41.23 & & \pm 9.99 & & \pm 23.97 & & \pm 1.79 & & \pm 2.99 & & \pm 2.99 & \\
\hline \multirow{2}{*}{ G4 } & $611.00^{a}$ & \multirow{2}{*}{102} & $184.24^{a}$ & \multirow{2}{*}{102} & $240.00^{a}$ & \multirow{2}{*}{120} & $36.33^{a}$ & \multirow{2}{*}{104} & $40.00^{b}$ & \multirow{2}{*}{95} & $40.61^{a}$ & \multirow{2}{*}{102} \\
\hline & \pm 38.87 & & \pm 10.13 & & \pm 9.97 & & \pm 2.00 & & \pm 2.81 & & \pm 2.81 & \\
\hline \multirow{2}{*}{ G5 } & $641.41^{a}$ & 103 & $185.00^{a}$ & 102 & $242.11^{a}$ & 121 & $37.00^{\mathrm{a}}$ & 106 & $39.71^{b}$ & 94 & $50.22^{a}$ & 102 \\
\hline & \pm 41.00 & & \pm 11.21 & & \pm 11.12 & & \pm 1.99 & 106 & \pm 2.41 & 94 & \pm 2.41 & \\
\hline$C_{6}$ & $587.77^{a}$ & 98 & $178.96^{a}$ & 99 & $210.11^{b}$ & 105 & $35.12^{\mathrm{b}}$ & 10 & $41.74^{a}$ & 9 & $40.02^{a}$ & 99 \\
\hline & \pm 36.21 & & \pm 10.21 & 99 & \pm 12.31 & 105 & \pm 2.31 & & \pm 2.99 & & \pm 2.99 & \\
\hline$C 7$ & $590.00^{a}$ & 98 & $178.11^{\mathrm{a}}$ & 98 & $212.97^{\mathrm{b}}$ & 106 & $36.10^{a}$ & 103 & $41.88^{a}$ & 99 & $39.99^{\mathrm{a}}$ & 98 \\
\hline $\mathrm{G} /$ & \pm 34.42 & 98 & \pm 11.00 & 98 & \pm 13.11 & 106 & \pm 2.12 & 103 & \pm 3.01 & 99 & \pm 3.01 & 98 \\
\hline
\end{tabular}


Table 5. Liver function of young mice groups treated by color wheat biscuits

\begin{tabular}{lccccccccc}
\hline & \multicolumn{2}{c}{ AST } & \multicolumn{2}{c}{ ALT } & AST/ALT & Bilirubin & \multicolumn{2}{c}{ ALP } \\
\cline { 2 - 11 } & $\mathrm{U} / \mathrm{L}$ & $\%$ & $\mathrm{U} / \mathrm{L}$ & $\%$ & Ratio & $\mathrm{mg} / \mathrm{dl}$ & $\%$ & $\mathrm{U} / \mathrm{L}$ & $\%$ \\
\hline G1 & $37.00^{\mathrm{ab}} \pm 2.11$ & 100 & $33.12^{\mathrm{b}} \pm 2.07$ & 100 & 1.12 & $0.241^{\mathrm{c}} \pm 0.021$ & 100 & $89.71^{\mathrm{a}} \pm 6.41$ & 100 \\
G2 & $35.11^{\mathrm{b}} \pm 3.41$ & 95 & $34.00^{\mathrm{b}} \pm 2.12$ & 103 & 1.03 & $0.232^{\mathrm{c}} \pm 0.019$ & 96 & $88.00^{\mathrm{a}} \pm 6.12$ & 98 \\
G3 & $34.71^{\mathrm{b}} \pm 3.00$ & 94 & $31.72^{\mathrm{b}} \pm 2.08$ & 102 & 1.03 & $0.222^{\mathrm{c}} \pm 0.020$ & 92 & $87.12^{\mathrm{b}} \pm 6.10$ & 97 \\
G4 & $40.00^{\mathrm{a}} \pm 2.71$ & 108 & $39.00^{\mathrm{a}} \pm 2.19$ & 118 & 1.03 & $0.301^{\mathrm{a}} \pm 0.024$ & 125 & $92.11^{\mathrm{a}} \pm 6.23$ & 103 \\
G5 & $39.27^{\mathrm{a}} \pm 3.24$ & 106 & $38.87^{\mathrm{a}} \pm 2.18$ & 117 & 1.01 & $0.311^{\mathrm{a}} \pm 0.022$ & 129 & $91.74^{\mathrm{a}} \pm 6.31$ & 102 \\
G6 & $38.00^{\mathrm{ab}} \pm 3.12$ & 103 & $36.11^{\mathrm{ab}} \pm 1.81$ & 109 & 1.05 & $0.270^{\mathrm{b}} \pm 0.021$ & 112 & $00.21^{\mathrm{a}} \pm 5.94$ & 100 \\
G7 & $38.61^{\mathrm{a}} \pm 2.88$ & 104 & $35.98^{\mathrm{ab}} \pm 1.92$ & 109 & 1.07 & $0.265^{\mathrm{b}} \pm 0.020$ & 110 & $90.73^{\mathrm{a}} \pm 5.88$ & 101 \\
\hline
\end{tabular}

\section{Conflict of Interest}

The authors declare that there are no conflicts of interest related to this article.

\section{References}

Abdel-Rahim EA, Ahmed EA, El-Desoky GE, Ramadan ME (1987). Biochemical role of some natural and synthetic colorants on liver function of rats. Mania Journal of Agriculture Research 9(3):11-17.

Abu El-Zahab HS, El-Khayal ZA, Awadallah R, Mahdy KA (1997). Physiological effects of some synthetic food coloring additives on rats. Bollettino Chimico Farmaceutico 136(10):615-627.

Allain CC, Poon LS, Chan CS, Richmoud W, Fu PC (1974). Enzymatic determination of total serum cholesterol. Clinical Chemistry 20(4):470475.

Arefin S, MohammadSH, ShammeAN, Mamun MD, Rashid M, Saddam $\mathrm{H}$ (2017). Tartrazine induced changes in physiological and biochemical parameters in Swiss albino mice. Marmara Pharmaceutical Journal 21(3):564569.

Ashida H, Hashimoto T, Tsuji S, Kanazawa K, Danno G (2000). Synergistic effects of food colors on the toxicity of 3-amino-1,4-dimethyl5H-pyrido[4,3-b]indole (Trp-P-1) inprimary cultured rat hepatocytes. Journal of Nutritional Science and Vitaminology 46(3):130-136.

Barrett A, Cooper A, Crumpler D, Dalen L, Grimshaw K, Kitchin E, Stevenson J (2007). Food additives and hyperactive behaviour in 3-year old and 8/9-year-old children in the community: a randomised, doubleblinded, placebo controlled trial. The Lancet 370(9598):1560-1567.

Belfield A, Golgberg D (1971). Colorimetric determination of alkaline phosphatase activity. Enzyme 12:561-566.

Burstein M (1970). A fully enzymatic colorimetric determination of HDL cholesterol in the serum. Lipid Research 11:583-595.

EL-Desoky GE, Abdel-Ghaffar A, AL-Othman ZA, Habilal MA, ALSheikh YA, Ghneim HK, ... Aboul-Soud MAM (2017). Curcumin protects against tartrazine-mediated oxidative stress and hepatotoxicity in male rats. European Review for Medical and Pharmacological Sciences 21:635-745.

Fossati P, Prencipe L (1982). Serum triglycerides determined coloimetrically with an enzyme that produces hydrogen peroxide. Clinical Chemistry 28(10):2077-2080.

Gao Y, Li C, Shen J, Yin H, An X, Jin H (2011). Effect of food azo dye tartrazine on learning and memory functions in mice and rats, and the possible mechanisms involved.Journal of Food Science 76:T125-129.
Hashem MM, Atta AH, Arbid MS, Nada SA, Asaad GF (2010). Immunological studies on Amaranth, Sunset Yellow and Curcumin as food coloring agents in albino rats. Food and Chemical Toxicology 48(6):1581-1586.

Hassan GM (2010). Effects of some synthetic coloring additives on DNA damage and chromosomal aberrations of rats. Arabian Journal of Biotechnology 13(1):13-24.

Himiri I, Bellahcen S, Souna F, Belmekki F, Aziz M, Bnouham M, ... Saaluri $\mathrm{E}$ (2011). A 90-day oral toxicity study of tartrazine, a synthetic food dye, in Wister rats. International Journal of Pharmacy and Pharmaceutical Sciences 3(2):159-169.

Haward CV (2005). Combining aspartame and quinoline yellow (MSG) and brilliant blue harms nerve cells eminent. Nano Toxicol 1:30.

Hayes AW (1994). Principles and methods of toxicology. Third Ed., Raven Press Ltd.,pp 687.

Knight JA, Anderson S, Rawle JM (1972). Chemical basis of sulfophosphor-vanillin reaction for estimation total serum lipid. Clinical Chemistry 18(6):1091-1101.

Levy AL (1981). A fully enzymatic colorimetric determination of $\mathrm{HDL}$ cholesterol in the serum. Clinical Chemistry27(5):653-662.

Lung A (1980). Encyclopedia of common natural ingredients used in food, drugs, and cosmetics.John Wiley, New Yorkpp313-314.

Neshe SA, Arefin S, Hussain MS, Das A, Karmakar P, Hossain MS (2016). Safety evaluation of chocolate brown dye in Swiss albino mice. International Journal of Nutritional Disorders and Therapy 6(195):2161-0509.

Reitman S, Frankel S (1957). A colorimetric method for the determination of serum glutamic oxaloacetic and glutamic pyruvic transaminases. American Journal ofClinical Pathology 28(56):56-62.

Soltan SS, Shehata MM (2012). The effects of using color foods of children on immunity properties and liver, kidney on rats. Food and Nutrition Sciences 3:897-904.

Stefanidou M, Alevisopoulos G, Chatziioannou A, Koutselinis A (2003). Assessing food additive toxicity using a cell model. Veterinary and Human Toxicology 45(2):103-105.

Walter M, Gerarde H (1970). Ultramicro method for the determination of conjugated and total bilirubin in serum or plasma. Microchemical Journal 15(2):231-236. 